A Survey of the Commitment and Reporting Practices of European Firms

\title{
Corporate Environment Performance
}

Unternehmensbewertung muss sich an Zielen und Umweltleistungen orientieren. Eine wesentliche Informationsquelle sind Umweltberichte. Wie breit und wie aussagekräftig ist diese Informationsbasis? Auf der Basis europäischer Daten geben die AutorInnen der OECD einen Überblick. Während immerhin über 40 Prozent der Unternehmen umweltpolitische Leitlinien formulieren, berichten weniger als 20 Prozent der Öffentlichkeit über ihre Umweltleistung, wenngleich mit stark steigender Tendenz. Gleichzeitig wird Umweltberichterstattung zunehmend zu einem wichtigen Baustein internationaler Regelwerke und Verhaltenskodizes.

M played a pivotal role in the expansion and deepening of globalisation. Public concerns about globalisation and, more particularly, about MNE activities have evolved in parallel with these developments. Governments, businesses and non-governmental organisations (NGOs), often acting in co-operation with one another, have taken steps to address these concerns, which straddle all aspects of the sustainable development agenda. Inter-governmental organisations have been active, as reflected in the Global Compact initiative in the United Nations and in the ongoing revision of the Organisation for Economic Cooperation and Development (OECD) Guidelines for Multinational Enterprises at OECD. Numerous industry and business associations and international organisations have gathered information regarding corporate responsibility and have taken initiatives. Individual companies have issued their own codes of conduct and have adopted management systems that help them meet their code commitments in their day-to-day operations. They develop reporting practices that help them communicate these efforts to the public. At the same time, a number of NGOs have played an important role in shaping and channelling corporate responsibility initiatives.

The present paper reports some preliminary results from a ,fact-finding" project that seeks to determine what firms are doing in the area of environmental commitment, management and reporting. Since it focuses on environmental issues, this paper covers only a fraction of the vast array of issues that firms cover in their codes. Work by the OECD Secretariat finds that, in addition to environmental management, company codes make commitments in a large number of areas including labour standards, human rights, combating corruption, competitive practices, consumer rights and reliable financial accounts and protection of shareholder rights. Environment and labour standards are, by far, the most frequently mentioned commitments in company codes (1).

The following analysis is based on the EIRIS database on environment management and reporting, which covers some 1600 publiclytraded firms in the UK and in continental Europe (2). The firms in the database range from large multinationals to small, quoted companies. The OECD aggregated this data in order to form an overall view of enterprises' practices in environmental commitment, management and reporting. The main focus of the present paper will be on environment reporting, although the paper also reports briefly on the first two headings.

\section{Policy commitment}

41 per cent of firms in the EIRIS database publish a statement on their environment commitments. The publication of an environmental policy is the first step that firms take towards responding to society's environmental concerns. Hence the number of firms with such an environment policy is naturally higher than those that are in more advanced stages of responsiveness - that is, of putting in place an environment management system ( 26 per cent) or a system of environmental reporting (21 per cent).

20 per cent of the total number of firms discuss their compliance standard - that is, where their commitments stand in relation to compliance with the law. Among these firms, a majority - 57 per cent - seems to be comfortable as long as they comply with the law. 38 per cent aim for a standard that exceeds compliance.

Industry and business associations have also developed codes, which firms may join or endorse (Figure 1). Some firms in the sample may not have fully developed their own environment policy, but by adhering to these initiatives, they can make public expressions of commitment on various environmental matters.

Publication of environment commitment is only the first step for environment responsibility. Firms also need to adopt various management practices - sometimes formalised as an explicit environmental management system - in order to make good on these commitments. Firms having such systems often seek to increase the credibility of their environmental commitments by publishing the details of their environment management systems.

Certification by third parties can help address the inherent problem of credibility associated with the study of codes. 14 per cent of the firms in the database have at least a part of the Com-

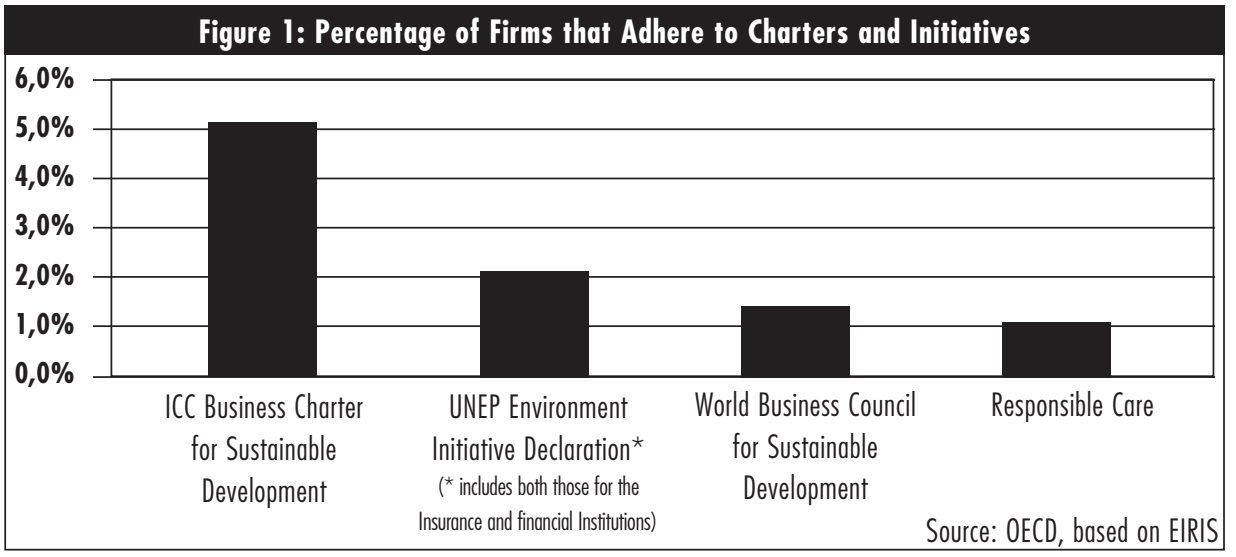


pany Group being certified by the Eco Management and Auditing System (EMAS) (seven per cent) or by the Management Standard ISO 14001 (twelve per cent), but in overwhelming majority of the cases the certifications cover less than one third of the total Company Group. Only two per cent of the firms have achieved either EMAS or ISO 14000 certification that covers the entire Company Group.

However, the institutional infrastructure required for reporting on the outcomes associated with the new management practices is relatively weak. In this context, there is a need to develop standards on what types of data a firm should report and how to ensure the accuracy of such data. In fact, environmental reporting is now a key issue on the agenda for increasing the business sector's responsiveness to environmental concerns.

\section{- Environmental reporting}

An increasing number of firms are publishing environment reports. 17 per cent of the firms in the EIRIS sample go beyond the reporting of commitment, basic environment policy and outline of the Environmental Management System, and make reports on environmental performance issues (3). Eight per cent of the firms produce a stand-alone environment report. The database suggests that the number of firms publishing environmental reports is rising rapidly.

There are large variations in the information that firms are willing to publish. There has been a suggestion to develop a common framework for environmental reporting. However, no agreed indicator is available at present. A group of NGOs, corporations, and business associations are working on the development of Global Reporting Initiative (GRI). The GRI, which is to provide guidelines for sustainability reporting by firms, is currently being implemented on a pilot basis by a number of large firms. Other guidelines, frameworks and standards have also been derived. Examples are guidelines by the London Benchmarking Group, Fondazione Eni Enrico Mattei, the European Chemical Industry Council, and Public Environment Reporting Initiative (4). In the absence of an agreed standard for environmental reporting, firms make their own choices. Thirteen per cent of the total number of companies - or 62 per cent of the firms that report some aspects of environment performance - provide some quantitative data in their reporting. Among those companies reporting quantitative data, 15 per cent report on all the key environmental issues identified by EIRIS. Seven per cent of all companies make reporting on some financial dimensions such as expenditure, capital investment, saving or additional income, environment liabilities, risk and provisions. In order to increase accountability, four per cent of the firms go further by reporting „bad news".

\section{A question of credibility}

The discussion so far suggests that, over time, firms are increasing their efforts to be accountable. However, in the absence of globally agreed environment standards, the inherent problem of credibility of company's environmental statements and reports remains. How do we know that the data on the environment reports are accurate, that they are based on sound collection and measurement methodologies and that the most relevant information appears in the report? Hence, the question comes back to the need for standards and channels for independent verification.

In the EIRIS database, nine per cent of companies mention independent verification. This is 43 per cent of firms that have published certain aspects of environment performance. Most of the firms embark on independent verification through EMAS registration in which independent verification of data accuracy is a criterion. Few companies use audits or verification beyond data accuracy.

\section{- Integration into broader control and reporting strategies}

Regulatory compliance figures prominently in the decision for firms to take on environment management certification system and some countries have integrated firm level reporting and management practices into their broader environmental enforcement strategies. For example, some countries, including Denmark, New Zealand, the Netherlands and one community in Belgium, have passed legislation on environmental reporting. Under the Denmark's ,green account" law that took effect in 1996, nearly 1000 Danish companies are now required to issue annual environmental reports. However, no consistent format and framework for environment reporting has emerged so far. Also noteworthy is the EU's move to incorporate voluntary initiatives into its enforcement strategy. In particular, its endorsement of EMAS and its recognition of ISO 14001 as an enabling standard has created an incentive for European firms to seek external certification of formal management systems and to undertake environmental reporting. At the international level, steps are also being taken to encou- rage environment reporting. Both OECD Principles for Corporate Governance and OECD Guidelines for Multinational Enterprises recommend the disclosure of non-financial information. However, these OECD instruments recognise that progress in this area requires an adequate environmental reporting framework. The discussions of the Guidelines review noted that strong synergies exist between instruments that reinforce international consensus on commitments for business conduct (such as the OECD Guidelines) and those that reinforce consensus on reporting standards for sustainable development (such as the Global Reporting Initiative, which receives some UN funding). It is for this reason that the revised OECD Guidelines for Multinational Enterprises are likely to contain language that „encourages" firms to move forward in this area, while also recognising that the required standards are still emerging.

\section{References}

(1) Gordon, Kathryn/ Miyake, Maiko: Deciphering Codes of Corporate Conduct: A Review of their Contents. OECD Directorate for Financial, Fiscal and Enterprise Affairs Working Papers on International Investment 02/1999.

(2) The research was jointly undertaken by researchers from the OECD and from the Ethical Investment Research Service (EIRIS). EIRIS is a UK independent research organisation serving investors that provides non-financial information on company environmental, social and ethical policy and practice. For more detail, see EIRIS: Corporate Environmental Policy, Management and Reporting, London 1999. The EIRIS database some contains 1600 firms in Europe (two-thirds UK firms and one-thirds continental Europeans). It covers firms in the Financial Times Stock Exchange Top 350 Index in UK and its equivalents in Europe. It contains data extracted from company's annual report, environment report and other materials, as well as publications by other parties, such as the EMAS Register.

(3) This corresponds to the number of Company Groups or parts of groups that report one of the following items: describtion of main impacts, quantitative data, performance against targets, bad news, financial dimensions, stakeholder relations, sustainability and independent verification.

(4) Environmental reporting clearinghouse website: http:// cei.sund.ac.uk

The views and data interpretations expressed in this paper are those of the authors and are not necessarily shared by the OECD.

\section{Die Autorlnnen}

Maiko Miyake und Kathryn Gordon sind wissenschaftliche MitarbeiterInnen der Abteilung International Investment and Multinational Enterprise der OECD . Kontakt: maiko.miyake@oecd.org, kathryn.gordon@oecd.org 
(c) 20I0 Authors; licensee IÖW and oekom verlag. This is an article distributed under the terms of the Creative Commons Attribution Non-Commercial No Derivates License (http://creativecommons.org/licenses/by-nc-nd/3.o/), which permits unrestricted use, distribution, and reproduction in any medium, provided the original work is properly cited. 